Doi: HTTPS://DOI.ORG/10.23910/IJBSM/2017.8.4.1816a

\title{
Evaluation of Organic Amendments Against Ralstonia solanacearum Causing Bacterial Wilt in Ginger
}

\author{
Roop Singh ${ }^{1 *}$, G. P. Jagtap ${ }^{1}$, Bannihatti R. K. ${ }^{1}$, T. K. Jatwa ${ }^{1}$, Irfan Khan ${ }^{2}$ and Neeraj Kumar Meena ${ }^{3}$ \\ ${ }^{1}$ Dept. of Plant Pathology, Vasantrao Naik Marathwada Agricultural University, Parbhani, Maharashtra (431 402), India \\ ${ }^{2}$ Dept. of Plant Pathology, Punjab Agricultural University, Ludhiana, Punjab (141 004), India \\ ${ }^{3}$ Dept. of Plant Pathology, Sam Higginbottom Institute of Agriculture, Technology and Sciences, Allahabad, U.P. (211 007), India
}

\section{Corresponding Author}

Roop Singh

e-mail: roop0008@gmail.com

\author{
Article History \\ Article ID: AR1816a

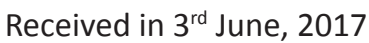 \\ Received in revised form $25^{\text {th }}$ July, 2017 \\ Accepted in $5^{\text {th }}$ August, 2017
}

\begin{abstract}
The present field study was undertaken to investigate the effective organic amendments against Ralstonia solanacearum under pot culture condition. The average (PESR+PESM) reduction in mortality recorded with all the organic amendments tested were ranged from 15.39 to $64.97 \%$ over untreated control. However, significantly highest reduction in average mortality was recorded with karanj cake (64.97\%). This was followed by the organic amendments viz., neem seed cake (43.95\%), farm yard manure (37.36\%), vermicompost (32.95\%), poultry manure $(32.24 \%)$ and sunflower seed cake $(26.87 \%)$. Whereas, safflower seed cake $(21.40 \%)$, goat manure $(19.28 \%)$, cotton seed cake (18.60\%) and groundnut cake (15.39\%) were found less effective. All the test amendments improve root length, shoot length and vigour index in ginger. Among the different amendments tested, significantly highest root length $(6.16 \mathrm{~cm})$, shoot length (12.56 cm) and vigour index (1372.73) were recorded with Karanj cake. The second best amendment found was neem seed cake $(5.26 \mathrm{~cm}, 10.26 \mathrm{~cm}$ and 931.20$)$ respectively. This was followed by the amendments viz., farm yard manure $(4.76 \mathrm{~cm}, 8.83 \mathrm{~cm}$ and 679.50$)$, vermicompost $(4.25 \mathrm{~cm}, 8.23$ $\mathrm{cm}$ and 582.44$)$, poultry manure $(4.23 \mathrm{~cm}, 6.56 \mathrm{~cm}$ and 467.53$)$, sunflower seed cake $(4.08 \mathrm{~cm}, 6.13 \mathrm{~cm}$ and 374.40$)$, safflower seed cake $(3.66 \mathrm{~cm}, 5.96 \mathrm{~cm}$ and 352.76$)$ for root length, shoot length and vigour index respectively.
\end{abstract}

Keywords: Ginger mortality, organic amendments, Ralstonia solanacearum, growth parameter

\section{Introduction}

India is considered as a "magical land of spices". No other country in the world has such a diverse variety of spice crops as India. Ginger (Zingiber officinale Roscoe) a very useful herb plant, is said to be originated from India, China and Java. It is grown throughout the tropical areas of the world and also commonly found in South East Asia especially in Indo Malaysia. The crop suffers from diseases like bacterial wilt caused by Ralstonia solanacearum, rhizome rot caused by Pythium spp., Fusarium spp., Sclerotium spp., Pseudomonas spp. and others (Dake and Edison, 1989; Senapati and Ghose, 2005; Paret et al., 2010; Sharma et al., 2010; Kavyashree, 2011). Out of the above mentioned diseases of ginger, Ginger production is curtailed by bacterial wilt, one of the most destructive diseases of the crop in tropical agriculture (Hayward, 1990). Sambasivam and Girija (2005) reported host resistant and loss in ginger cultivation by $R$. solanacearum in Kerala. Many times this important cash crop is subjected to premature wilting resulting in $100 \%$ crop loss. Bacterial wilt, caused by Ralstonia solanacearum formerly known as Pseudomonas solanacearum
(Smith) is one of the most serious soil-borne disease (Hayward, 2000). Bacterial wilt disease was widely distributed in tropical, subtropical and warm temperate regions of the world with a host range of 44 plant families (Hayward, 1991; Poussier et al., 1999; Kumar et al., 2004). Sharma and Jain (1978) identified that causal agent of bacterial wilt of ginger is Ralstonia solanacearum (Smith) Yabuuchi, biotype III. R. solanacearum causing wilt disease is one of the major constraints of ginger in small and marginal farming communities. The strain causing bacterial wilt of ginger in India belongs either to biovar 3 or 4; the former being the most virulent in India (Kumar and Sarma, 2004; Kumar and Hayward, 2005). The characteristic symptoms of bacterial wilt of ginger include green leaves roll and curl due to water stress caused by bacteria blocking the water-conducting vascular system of the ginger stems, leaf yellowing and necrosis (Nelson, 2013; White et al., 2013).

The aim of present investigation was to study the effect of organic inputs on growth of Ralstonia solanacearum and management of wilt disease of ginger under glass house conditions. 


\section{Materials and Methods}

The present field study was undertaken at Department of Plant Pathology, College of Agriculture, Vasantarao Naik Marathwada Krishi Vidyapeeth, Parbhani during August 2014 to June, 2015 to investigate the effective organic amendments against Ralstonia solanacearum under pot culture condition. The experiment was laid in Complete Randomized Design (CRD) and imposed following treatments with three replications under each of them. To conduct the study a total of 10 organic amendments viz., FYM, poultry manure, neem seed cake, sunflower seed cake, vermicompost, cotton seed cake, karanj cake, goat manure, groundnut cake and safflower seed cake were evaluated against $R$. solanacearum by sick soil method in pot culture under screen house conditions. Except vermicompost, all the test amendments were crushed physically to rough powder and used for soil application.

The earthen pots ( $30 \mathrm{~cm}$ dia.) disinfected with $5 \%$ solution of Copper sulphate were filled with autoclaved potting mixture of soil:sand:FYM (2:1:1). The mass multiplied (48 hr old nutrient broth culture: $2 \times 10^{8} \mathrm{cfu} \mathrm{m}^{-1}$ ) of $R$ solanacearum was drenched (@50 ml kg-1 potting mixture) evenly to the potting mixture in pots, these pots were incubated for $96 \mathrm{hrs}$ in screen house to proliferate the bacterium and make the soil/potting mixture sick.

The coarse ground test amendments were applied (@ $50 \mathrm{~g}$ $\mathrm{kg}^{-1}$ mixture) in the earthen pots containing test bacterium sick soil/potting mixture, mixed thoroughly, watered regularly and maintained in screen house. After $72 \mathrm{hrs}$ of amendments application, surface sterilized $\left(0.1 \% \mathrm{HgCl}_{2}\right)$ healthy rhizome of ginger were sown (10 rhizomes pot ${ }^{-1}$ ), watered regularly and maintained in the screen house. Three pots/treatment/ replication were maintained. The earthen pots containing $R$. solanacearum sick soil and sown with surface sterilized healthy rhizome of ginger, without amendment were maintained as untreated control. The percentage seed germination, preemergence seed rot, post-emergence seedling mortality and vigour index were calculated.

\section{Results and Discussion}

A total of 10 amendments were evaluated as pre-sowing soil application to assess their efficacy against $R$. solanacearum, employing sick soil technique and sowing susceptible ginger local variety in pot culture under glass house conditions.

\subsection{Effect of seed germination and mortality}

Results (Table 1 ) revealed that all the test amendments recorded significantly improved rhizome germination, over untreated control and it was ranged from 30.00 to $73.33 \%$, as against $20.00 \%$ in untreated control. However, significantly highest rhizome germination was recorded with karanj cake (73.33). This was followed by the amendments viz., neem seed cake $(60.00 \%)$, farm yard manure $(50.00 \%)$, vermicompost $(46.67 \%)$, poultry manure $(43.33 \%)$, sunflower seed cake and safflower seed cake (each $36.67 \%$ ). Whereas, cotton seed cake, goat manure (each $33.33 \%$ ) and groundnut cake $(30.00 \%)$ were found least effective with comparatively

Table 1: Effect of organic amendment on pre-emergence rhizome rot and post emergence seedling mortality caused by $R$. solanacearum in ginger

\begin{tabular}{|c|c|c|c|c|c|c|c|}
\hline \multirow[t]{2}{*}{ Tr. No. } & \multirow{2}{*}{$\begin{array}{c}\text { Germination } \\
(\%)\end{array}$} & \multicolumn{2}{|c|}{ Rot/ mortality (\%) ${ }^{*}$} & \multirow{2}{*}{$\begin{array}{c}\text { Average } \\
\text { mortality (\%) }\end{array}$} & \multicolumn{2}{|c|}{ Reduction over control (\%) } & \multirow{2}{*}{$\begin{array}{c}\text { Average } \\
\text { reduction (\%) }\end{array}$} \\
\hline & & PESR & PESM & & PESR & PESM & \\
\hline $\mathrm{T}_{1}$ & $50.00(45.00)$ & $50.00(45.00)$ & $54.33(47.48)$ & $52.16(46.23)$ & $37.50(37.76)$ & $37.22(37.59)$ & $37.36(37.67)$ \\
\hline $\mathrm{T}_{2}$ & $43.33(41.16)$ & $56.66(48.82)$ & $55.67(48.25)$ & $56.16(48.53)$ & $29.16(32.68)$ & $35.32(36.46)$ & $32.24(34.59)$ \\
\hline $\mathrm{T}_{3}$ & $60.00(50.76)$ & $40.00(39.23)$ & 53.66 (47.09) & $46.83(43.18)$ & $50.00(45.00)$ & $37.91(38.00)$ & $43.95(41.52)$ \\
\hline $\mathrm{T}_{4}$ & $36.67(37.26)$ & $63.33(52.73)$ & $58.00(49.60)$ & $60.66(51.15)$ & $20.83(27.15)$ & $32.91(35.00)$ & $26.87(31.22)$ \\
\hline $\mathrm{T}_{5}$ & $46.67(43.09)$ & $53.33(46.90)$ & $58.33(49.79)$ & $55.83(48.340$ & $33.33(35.26)$ & $32.58(34.80)$ & $32.95(35.03)$ \\
\hline $\mathrm{T}_{6}$ & $33.33(35.26)$ & $66.66(54.73)$ & $68.66(55.95)$ & $67.66(55.34)$ & $16.66(24.08)$ & $20.55(26.95)$ & $18.60(25.54)$ \\
\hline $\mathrm{T}_{7}$ & $73.33(58.90)$ & $26.67(31.09)$ & $31.66(34.24)$ & $29.16(32.68)$ & $66.66(54.73)$ & $63.28(52.70)$ & $64.97(53.71)$ \\
\hline $\mathrm{T}_{8}$ & $33.33(35.26)$ & $66.67(54.73)$ & $67.50(55.24)$ & 67.08 & $16.66(24.08)$ & $21.91(2$ & 26.04) \\
\hline $\mathrm{T}_{9}$ & $30.00(33.21)$ & $70.00(56.78)$ & $70.66(57.20)$ & 70.33 (56.99) & $12.50(20.70)$ & $18.28(25.31)$ & 15.39 (23.09) \\
\hline $\mathrm{T}_{10}$ & 36.67 (37.26) & $63.33(52.73)$ & $67.33(55.13)$ & $65.33(53.92)$ & $20.83(27.15$ & 21.98 (27.95) & $21.40(27.55)$ \\
\hline $\mathrm{T}_{11}$ & $20.00(26.56)$ & $80.00(63.43)$ & $86.66(68.57)$ & $83.33(65.90)$ & $0.00(0.00)$ & $0.00(0.00)$ & $0.00(0.00)$ \\
\hline SEm \pm & 2.66 & 3.18 & 2.44 & 2.81 & 3.35 & 3.11 & 3.23 \\
\hline $\mathrm{CD}(p=0.01)$ & 7.80 & 9.32 & 7.14 & 8.23 & 9.83 & 9.12 & 9.47 \\
\hline
\end{tabular}

$\mathrm{T}_{1}$ : FYM; $\mathrm{T}_{2}$ : Poultry manure; $\mathrm{T}_{3}$ : Neem seed cake; $\mathrm{T}_{4}$ : Sunflower cake; $\mathrm{T}_{5}$ : Vermicompost; $\mathrm{T}_{6}$ : Cotton seed cake; $\mathrm{T}_{7}$ : Karanj cake; $\mathrm{T}_{8}$ : Goat manure; $\mathrm{T}_{9}$ : Groundnut cake; $\mathrm{T}_{10}$ : Safflower cake; $\mathrm{T}_{11}$ : Control (Untreated); *-Mean of three replications; Figures in parentheses are angular transformed values 
minimum rhizome germination.

All the organic amendments applied in sick soil ( $R$. solanacearum) were found effective against $R$. solanacearum and recorded pre-emergence seed rot in the range of 26.67 to $70.00 \%$ as against $80.00 \%$ in untreated control. However, significantly least pre-emergence seed rot was recorded with the amendment karanj cake (26.67\%). This was followed by the amendment viz., neem seed cake (40.00\%), farm yard manure $(50.00 \%)$, vermicompost $(53.33 \%)$, poultry manure $(56.66 \%)$, sunflower seed cake and safflower seed cake (each $63.33 \%$ ). Whereas, cotton seed cake, goat manure (each 66.66 $\%)$ and groundnut cake $(70.00 \%)$ were found less effective (Figure 1).

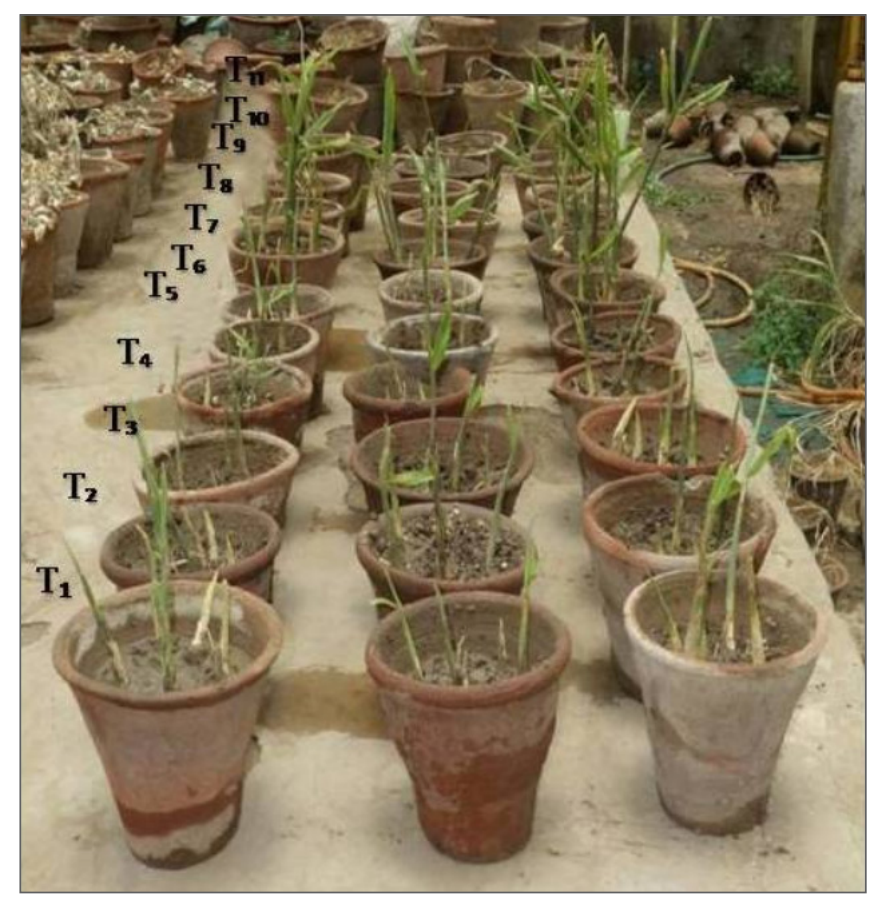

Figure 1: Effect of organic amendments against R. solanacearum

All the organic amendments tested were found effective against $R$. solanacearum and recorded post-emergence seedling mortality in the range of 31.66 to $70.66 \%$ as against $86.66 \%$ in untreated control. However, significantly least pre-emergence seedling mortality was recorded with the amendment karanj cake (31.66\%). This was followed by neem seed cake (53.66\%), farm yard manure $(54.33 \%)$, poultry manure $(55.67 \%)$, sunflower seed cake $(58.00 \%)$ and vermicompost (58.33\%). Whereas, safflower seed cake $(67.33 \%)$ goat manure $(67.50 \%)$, cotton seed cake $(68.66 \%)$, groundnut cake (70.66\%), were found less effective.

The average mortality (PESR+PESM) recorded with all the treatments were ranged from 29.16 to $70.33 \%$ as against $83.33 \%$ in untreated control. However, significantly least average mortality was recorded with the amendment karanj cake (29.16\%). This was followed by neem seed cake $(46.83 \%)$, farm yard manure (52.16\%), vermicompost (55.83\%), poultry manure (56.16\%) and sunflower cake (60.66\%). Whereas, safflower seed cake (65.33\%), goat manure (67.08\%), cotton seed cake (67.66\%) and groundnut cake $(70.33 \%)$ were found less effective.

The average (PESR+PESM) reduction in mortality recorded with all the organic amendments tested were ranged from 15.39 to $64.97 \%$ as against $0.00 \%$ in untreated control. However, significantly highest reduction in average mortality was recorded with karanj cake (64.97\%). This was followed by the organic amendments viz., neem seed cake (43.95\%), farm yard manure (37.36\%), vermicompost (32.95\%), poultry manure (32.24\%) and sunflower seed cake (26.87\%). Whereas, safflower seed cake (21.40\%), goat manure (19.28\%), cotton seed cake (18.60\%) and groundnut cake (15.39\%) were found less effective.

Thus, all the organic amendments applied in sick soil ( $R$. solanacearum) were found effective in reducing the preemergence seed rot as well as post-emergence seedling mortality in ginger. However, karanj cake was found most effective with highest average reduction in mortality. In the order of merit of effectiveness in reducing mortality, the other organic amendments found effective were neem seed cake, farm yard manure, vermicompost, poultry manure, sunflower seed cake, safflower seed cake, goat manure, cotton seed cake and groundnut cake.

\subsection{Effect on growth parameters}

Results (Table 2 ) revealed that all the test amendments

Table 2: Effect of organic amendments application on growth parameters in ginger against $R$. solanacearum

\begin{tabular}{lcccc}
\hline Tr. No. & $\begin{array}{c}\text { Germination } \\
(\%)^{*}\end{array}$ & $\begin{array}{c}\text { Root } \\
\text { length } \\
(\mathrm{cm})^{*}\end{array}$ & $\begin{array}{c}\text { Shoot } \\
\text { length } \\
(\mathrm{cm})^{*}\end{array}$ & $\begin{array}{c}\text { Vigour } \\
\text { index }\end{array}$ \\
\hline $\mathrm{T}_{1}$ & $50.00(45.00)$ & 4.76 & 8.83 & 679.50 \\
$\mathrm{~T}_{2}$ & $43.33(41.16)$ & 4.23 & 6.56 & 467.53 \\
$\mathrm{~T}_{3}$ & $60.00(50.76)$ & 5.26 & 10.26 & 931.20 \\
$\mathrm{~T}_{4}$ & $36.67(37.26)$ & 4.08 & 6.13 & 374.40 \\
$\mathrm{~T}_{5}$ & $46.67(43.09)$ & 4.25 & 8.23 & 582.44 \\
$\mathrm{~T}_{6}$ & $33.33(35.26)$ & 4.60 & 6.70 & 376.62 \\
$\mathrm{~T}_{7}$ & $73.33(58.90)$ & 6.16 & 12.56 & 1372.73 \\
$\mathrm{~T}_{8}$ & $33.33(35.26)$ & 3.66 & 5.13 & 282.97 \\
$\mathrm{~T}_{9}$ & $30.00(33.21)$ & 3.06 & 6.20 & 277.80 \\
$\mathrm{~T}_{10}$ & $36.67(37.26)$ & 3.66 & 5.96 & 352.76 \\
$\mathrm{~T}_{11}$ & $20.00(26.56)$ & 2.36 & 5.53 & 157.80 \\
$\mathrm{SEm} \pm$ & 2.66 & 0.25 & 0.53 & - \\
$\mathrm{CD}(p=0.01)$ & 7.8 & 0.73 & 1.55 & - \\
\hline
\end{tabular}

*: Mean of three replications; Figures in parentheses are angular transformed values 
improve root length, shoot length and vigour index in ginger. Among the different amendments tested, significantly highest root length $(6.16 \mathrm{~cm})$, shoot length $(12.56 \mathrm{~cm})$ and vigour index (1372.73) were recorded with Karanj cake. The second best amendment found was neem seed cake $(5.26 \mathrm{~cm}$, $10.26 \mathrm{~cm}$ and 931.20$)$ respectively. This was followed by the amendments viz., farm yard manure $(4.76 \mathrm{~cm}, 8.83 \mathrm{~cm}$ and $679.50)$, vermicompost $(4.25 \mathrm{~cm}, 8.23 \mathrm{~cm}$ and 582.44$)$, poultry manure $(4.23 \mathrm{~cm}, 6.56 \mathrm{~cm}$ and 467.53$)$, sunflower seed cake $(4.08 \mathrm{~cm}, 6.13 \mathrm{~cm}$ and 374.40$)$, safflower seed cake $(3.66 \mathrm{~cm}$, $5.96 \mathrm{~cm}$ and 352.76) for root length, shoot length and vigour index respectively. Rest of the amendments except cotton seed cake, goat manure and groundnut cake were found at par to each other and recorded root length 4.60, 3.66, 3.06 $\mathrm{cm}$, shoot length $6.70,5.13,6.20 \mathrm{~cm}$ and vigour index 376.62 , $282.97,277.80$, respectively, as against significantly least root length $(2.36 \mathrm{~cm})$, shoot length $(5.53 \mathrm{~cm})$ and vigour index (157.80) was found in untreated control.

Results of the present study obtained for the organic amendments viz., karanj cake, neem seed cake, farm yard manure, vermicompost, poultry manure, sunflower seed cake, safflower seed cake, goat manure, cotton seed cake and groundnut cake against $R$. solanacearum are in conformity with those reported earlier by several workers (Lemaga et al., 2001; Schonfeld et al., 2003; Islam and Toyota, 2004; Reddy et al., 2012). Karanj cake found effective in reducing the Ralstonia population, maximum plant survival and increase in the yield (Sharma and Kumar, 2000: Sharma and Kumar, 2004). Sharma and Kumar (2009) reported that karanj (Pongamia) cake resulted 30.5 and $33.2 \%$ reduction in initial Ralstonia population at 10 and $20 \mathrm{~kg} \mathrm{ha}^{-1}$ doses respectively. Disease suppression and survival of the pathogen in the soil differed depending on amendment type and application rate. Higher disease severity was recorded in soil amended with $10 \%$ green compost compared to the control treatment. Complete suppression of $R$. solanacearum was observed in pots amended with 5 and $10 \%$ farm yard manure, $1 \%$ green compost and $10 \%$ coco peat (Yadessa et al., 2010).

\section{Conclusion}

Bacterial wilt is one of the major constraints in the production of ginger, causing heavy quantitative as well as qualitative losses. The studies on evaluation of different organic amendments against bacterial wilt ( $R$. solanacearum) disease under pot culture conditions indicated that highest reduction in average mortality was recorded with karanj cake. This was followed by the organic amendments viz., neem seed cake, farm yard manure and vermicompost were found most effective and economical for the management of bacterial wilt of ginger.

\section{References}

Dake, G.N., Edison, S., 1989. Association of pathogens with rhizome rot of ginger in Kerala. Indian Phytopathology,
42(1), 116-119.

Hayward, A.C., 1991. Biology and epidemiology of bacterial wilt caused by Pseudomonas solanacearum. Annual Review Phytopathology 29, 65-87.

Hayward, A.C., 2000. Ralstonia solanacearum. Encyclopedia of Microbiology 4, 32-42.

Hayward, A.C., El-Nashaar, H.M., Nydegger, U., De Lindo, L., 1990.Variation in nitrate metabolism in biovars of Pseudomonas solanacearum. Journal of Applied Bacteriology 69, 269-280.

Islam, T.M.D., Toyota, K., 2004. Suppression of bacterial wilt of tomato by Ralstonia solanacearum by incorporation of composts in soil and possible mechanism. Microbes Environment 19, 53-60.

Kavyashree, R., 2009. An efficient in vitro protocol for clonal multiplication of Ginger var. Varada. Indian Journal of Biotechnology 8, 328-331.

Kumar, A., Hayward, A.C., 2005. Bacterial diseases of ginger and their control. In: Ravindran, P.N., Babu, K.N. (Eds), Monograph on ginger. CRC Press, Boca Raton 341-366.

Kumar, A., Sarma, Y.R., 2004. Characterization of Ralstonia solanacearum causing bacterial wilt of ginger in India. Indian Phytopathology 57, 12-17.

Kumar, A., Sarma, Y.R., Anandaraj, M., 2004. Evaluation genetic diversity of Ralstonia solanacearum causing bacterial wilt of ginger using Rep-PCR and RFLP-PCR. Current Sciience 87, 1555-1561.

Lemaga, B., Siriri, D., Ebayant, P., 2001. Effect of soil amendments on bacterial wilt incidence and yield of potatoes in Southwestern Uganda. African Crop Science Journal 9(1), 267-276.

Nelson, S., 2013. Bacterial wilt of edible ginger in Hawaii. Plant Disease, 99.

Paret, M.L., Cabos, R., Kratky, B.A., Alvarez, A.M., 2010. Effect of plant essential oils on Ralstonia solanacearum Race 4 and bacterial wilt of edible ginger. Plant Disease 94(5), 521-527.

Poussier, S., Vandewalle, P., Luisetti, J., 1999. Genetic Diversity of African and worldwide strains of $R$. solanacearum as determined by PCR-Restriction fragment length polymorphism analysis of the $h r p$ gene region. Applied and Environmental Microbiology 65(5), 2184-2194.

Reddy, S.A., Bagyaraj, D.J., Kale, R.D., 2012. Vermicompost as a biocontrol agent in suppression of two soil-borne plant pathogens in the field. Acta Biologica Indica 1(2), 137-142.

Sambasivam, P.K., Girija, D., 2006. Biochemical characterization of Ralstonia solanacearum infecting Ginger. Annals of Plant Protection Sciences 14(2), 419-423.

Schonfeld, J.A., Gelsomino, L.S., Van, O.A., Gorissen, K.S., Van, J.D., 2003. Effects of compost addition and stimulated solarization on the fate of Ralstonia solanacearum biovar 2 and indigenous bacteria in soil. FMES Microbiology of Ecology 43, 63-74. 
Senapati, A.K., Ghose, S., 2005. Screening of ginger varieties against rhizome rot disease complex in eastern ghat high land zone of Orissa. Indian Phytopathology 58(4), 437-439.

Sharma, B.R., Dutta, S., Roy, S., Debnath, A., Roy, M.D., 2010. The effect of soil physico-chemical properties on rhizome rot and wilt disease complex incidence of ginger under hill agro-climatic region of West Bengal. Plant Pathology Journal 26(2), 198-202.

Sharma, J.P., Kumar, S., 2000. Management of Ralstonia wilt through soil disinfectant mulch, lime and cakes in tomato (Lycopersican escculentum). Indian Journal of Agricultural Sciences 70, 17-19.

Sharma, J.P., Kumar, S., 2004. Performance of elite lines of tomato for resistance to wilt caused by Pseudomonas solanacerum. Indian Journal of Agricultural Sciences, 67, 175-176.
Sharma, J.P., Kumar, S., 2009. Linear reduction of propagules of Ralstonia solanacearum in soil by cake and chemicals. Indian Phytopathology 62(1), 49-53.

Sharma, N.D., Jain, A.C., 1978. Studies on the biological control of Fusarium oxysporium f. sp. Zingiberi. The causal organism of yellows disease of ginger. Indian Phytopathology 31, 260-261.

White, F., Motomura, S., Miyasaka, S., Kratky, B.A., 2013. A simplified method of multiplying bacterial wilt-free edible ginger (Zingiber officinale) in Pots. Plant Disease, 93.

Yadessa, G.B., Van Bruggen, A.H.C., Ocho, F.L., 2010. Effects of different soil amendments on bacterial wilt caused by Ralstonia solanacearum and on the yield of tomato. Journal of Plant Pathology 92(2), 439-450. 